\title{
ALGIERS RADIOCARBON MEASUREMENTS I
}

\section{O. RAHMOUNI, C. ROUSSILLOT, and F. ARMANET}

Service des Applications Nucléaires, Algiers, B.P. 1147, Algeria

The following list shows the age measurements made at Algiers by the Service des Applications Nucléaires using the $\mathrm{C}^{14}$ method. The laboratory was created in 1965 to answer the increasing demand of the archaeologic research in $\mathrm{N}$ Africa, and made its first measurements in 1967. The electronic apparatus employed was completed and calibrated in 1968 and the first tests were performed during the same year. Regular dating-test samples started in June, 1968. The electronic circuits are of commercial origin or made in the $\mathrm{C}^{14}$ Laboratory.

We follow the method used in the Gif s/Yvette Dating Laboratory. Samples are examined and foreign matter is removed. They are treated by leaching in a $5 \% \mathrm{NH}_{4} \mathrm{OH}$ solution, and then in a $\mathrm{N} / 10 \mathrm{HCl}$ solution. Samples are rinsed in distilled water and dried. Our filling gas, $\mathrm{CO}_{2}$, is prepared by burning in a stream of oxygen and purified by passage through hot $\mathrm{CuO}, \mathrm{AgNO}_{3}$ solution, and $\mathrm{H}_{2} \mathrm{SO}_{4}-\mathrm{CrO}_{3}$ solution; then it is precipitated as barium carbonate by bubbling in a $\mathrm{Ba}(\mathrm{OH})_{2}$ solution. Sulfuric acid is used to liberate $\mathrm{CO}_{2}$ from $\mathrm{BaCO}_{3}$. Shells are only washed (twice) in hot distilled water and dried. They are not burnt, but directly attacked by sulfuric acid to liberate $\mathrm{CO}_{2}$.

After purification by fractional crystallization, the gas is stored in flasks for ca. 30 days to eliminate the radon that may result from impurity of the reagents. Final purification is performed by absorption of $\mathrm{CO}_{2}$ on alumina followed by desorption at room temperature, and by passage through a $\mathrm{P}_{2} \mathrm{O}_{5}$ column before and after a second fractional crystallization. This has proved particularly effective and gives a very good filling gas.

The counting unit is a 1.2 liter OFHC copper proportional counter and its filling is made at fixed pressure of $740 \mathrm{~mm} \mathrm{Hg}$. The counter is protected by a shield of $20 \mathrm{~cm}$ of lead and $5 \mathrm{~cm}$ of iron, and by a cylindrical crown of $2 \mathrm{~cm}$ of mercury. Anticoincidence shielding is provided by 36 Geiger-Müller tubes, surrounding the sample counter standing in the mercury crown. Working voltage is $4.7 \mathrm{kV}$ with a plateau length of more than $500 \mathrm{~V}$. Measurements are made in an air-conditioned room. Sample counts (of $1000 \mathrm{~min}$ ) are repeated several times to give a total time of at least $5000 \mathrm{~min}$. Background measurements were made by using industrial $\mathrm{CO}_{2}$ from coke-ovens delivered in bombs. Our background is $1.40 \mathrm{count} / \mathrm{min}$ (error is $\pm \sigma$ ). The modern $\mathrm{C}^{14}$ standard $(1950)$ is obtained from NBS oxalic acid standard multiplied by 0.95 . The modern filling gas is prepared by wet oxidation of oxalic acid with potassium permanganate in acid solution. Dates are calculated on the Libby halflife value $\left(\mathrm{T}^{1 / 2}=5568 \pm 30 \mathrm{yr}\right)$. To test the linearity of our detector we measured artificial samples containing variable known percentages of 
$\mathrm{C}^{14}$ and we found expected values. Some measurements on several samples already checked by other laboratories (Gif s/Yvette, Monaco, Nancy) are in agreement with ours; some of these are given in this list.

\section{ACKNOWLEDGMENTS}

We are grateful to J. Labeyrie and G. Delibrias and her collaborators for their continuous support, and to many in the Institut d'Etudes Nucléaires who gave us technical advice. We also thank Y. Pinatel, S. A. Boutemine, and R. Ait Ameur for their valuable help in routine work, as well as B. Abdelkader and O. L. Belaguida who preceded us in the laboratory. Sample descriptions were prepared in collaboration with collectors and submitters of samples. Most of them were submitted by the Centre Algérien de Recherches Archéologiques, Préhistoriques et Ethnographiques (C.A.R.A.P.E.), the others were submitted by the Service des Antiquités d'Algérie (Sous-Direction des Beaux-Arts).

\section{SAMPLE DESCRIPTIONS}

\section{ALG-3. Rassel}

$14,270 \pm 590$ 12,320 B.c.

Terrestrial shells from lower level in a demolished cave on the seaside near Tipasa, Dept. Algiers (36 $38^{\prime} \mathrm{N}$ Lat, $2^{\circ} 24^{\prime} \mathrm{E}$ Long) Algeria. Coll. 1967 and subm. by C. Brahimi, C.A.R.A.P.E. Comment: sample is assoc. to an Ibero-Maurusian industry. It is the oldest date known for the Epipaleolithic culture.

\section{Tamar Hat series, Algeria}

Charcoal from a layer of a shelter in rocks at Tamar Hat, Souk el

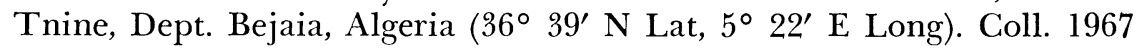
and subm. by C. Brahimi.

\section{ALG-5. Tamar Hat 2-99}

$10,350 \pm 375$

Charcoal found in the superficial part $(0$ to $30 \mathrm{~cm})$ of the upper level.

\section{ALG-4. Tamar Hat 1.98}

$12,450 \pm 480$

Charcoal found in a deeper area $(30$ to $50 \mathrm{~cm}$ ) of the upper level. General Comment: presence of an Ibero-Maurusian lithic industry.

\section{ALG-7. Ain Boucherit 2}

$5540 \pm 190$

3590 B.c.

Charcoal from a deep level $(120$ to $140 \mathrm{~cm})$ in a snailery of Upper Capsian from Aïn Boucherit, El Eulma, near Setif $\left(36^{\circ} 13^{\prime} \mathrm{N}\right.$ Lat, $5^{\circ} 39^{\prime}$ E Long). Coll. 1966 and subm. by G. Camps, C.A.R.A.P.E. Comment: expected age, also dated by Nancy Natural Radiocarbon Lab. (Ny-76, $3170 \pm 130$ B.c., Radiocarbon, 1968, v. 10, p. 123). 
Dahmous El Ahmar series, Algeria

Snail and ostrich egg shells from archaeologic layer of ashes from a snailery in cave near Tebessa, Dept. Annaba $\left(33^{\circ} 21^{\prime} 12^{\prime \prime} \mathrm{N}\right.$ Lat, $8^{\circ} 5^{\prime}$ 25" E Long) Algeria. Coll. 1964 and subm. by C. Roubet, C.A.R.A.P.E.

\section{ALG-10. Dahmous El Ahmar 1}

$5720 \pm 195$

Snail shells.

3770 B.c.

ALG-11. Dahmous El Ahmar 2

$5400 \pm 190$

Ostrich eggs.

General Comment: Neolithic of Capsian tradition.

\section{Ain Naga series, Algeria}

Samples from Aïn Naga, Messad, Dept. Titteri, Algeria $\left(34^{\circ} 21^{\prime} \mathrm{N}\right.$ Lat, $3^{\circ} 29^{\prime}$ E Long). Coll. 1968 and subm. by D. Grebenart, C.A.R.A.P.E.

\section{ALG-12. Ain Naga 4}

$9300 \pm 300$

Terrestrial shells (Helix) 20 to $30 \mathrm{~cm}$ deep in the Epipaleolithic deposit of Upper Capsian and Neolithic layer.

\section{ALG-13. Ain Naga 5}

$8900 \pm 280$

6950 в.c.

Terrestrial shells (Helix) found in a deeper area (30 to $40 \mathrm{~cm}$ ). General Comment: though deeper than the last one, this sample was dated younger. Both dates agree with the age of charcoal from the same level (7220 \pm 200 B.C., Gif-1220, unpub.). Charcoal from Neolithic layer was dated $5550 \pm 220$ B.c. (Gif-1221, unpub.).

\section{El Marmouta series, Algeria}

Samples from El Marmouta, Lioua, Dept. Batna (34 $35^{\prime} \mathrm{N}$ Lat, $5^{\circ}$ 21' E Long) Algeria. Coll. 1967 and subm. by D. Grebenart.

\section{ALG-18. El Marmouta 4}

$6450 \pm 260$

Fragments of ostrich eggs.

ALG-20. El Marmouta 5

Fragments of ostrich eggs.

General Comment: superficial deposit in Upper Capsian layer.

\section{Rabah series, Algeria}

Samples from Rabah, Ouled Djellal, Dept. Batna, Algeria $\left(34^{\circ} 26^{\prime}\right.$ $\mathrm{N}$ Lat, 58' E Long). Coll. 1968 and subm. by D. Grebenart.

\section{ALG-17. Rabah 15}

Fragments of ostrich eggs. 
ALG-22. Rabah 12

$7000 \pm 280$

Fragments of ostrich eggs.

5050 B.C.

ALG-23. Rabah 16

$6980 \pm 275$

Fragments of ostrich eggs.

5030 B.c.

ALG-8. Rusguniae

$1380 \pm 115$

A.D. 570

Charcoal from Rusguniae, Cap Matifou, Dept. Algiers $\left(36^{\circ} 40^{\prime} \mathrm{N}\right.$ Lat, $3^{\circ}$ 14' E Long) Algeria. Coll. by M. Guéry, Service des Antiquités d'Algérie, subm. by G. Camps. Comment: stratigraphic study of postRoman dwelling places previously occupied by the Romans. Sample coll. at $80 \mathrm{~cm}$ depth.

\section{Tebessa series, Algeria}

Charcoal from Tebessa, Dept. Annaba, Algeria $\left(35^{\circ} 20^{\prime} \mathrm{N}\right.$ Lat, $8^{\circ}$ $0^{\prime} 41^{\prime \prime}$ E Long). Coll. 1967 by M. Lequément, Service des Antiquités d'Algérie; subm. by G. Camps.

ALG-14. Tebessa 1

Charcoal.

ALG-15. Tebessa 2

Charcoal.

ALG-9. Tebessa 3

Charcoal.

General Comment: stratigraphic study of the different medieval dwelling places which succeeded in the Roman theater from the Byzantine, through the Moslem period, up to now. Dates were expected.

ALG-21. Medracen

$2170 \pm 155$

220 B.C.

Wood from a beam propping the inside gallery of a Berber funeral

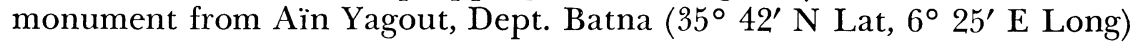
Algeria. Coll. 1969 and subm. by G. Camps.

ALG-24. Tipasa

$2060 \pm 140$

110 B.c.

Charcoal from Tipasa, Dept. Algiers ( $36^{\circ} 30^{\prime} \mathrm{N}$ Lat, $2^{\circ} 26^{\prime} \mathrm{E}$ Long) Algeria. Coll. 1967 and subm. by S. Lancel, Fac. Lettres et Sci. Humaines d'Alger. Comment: sample was found in a wood shed used for incineration in a pre-Roman necropolis.

REFERENCES

Armanet, F., Roussillot, C., Rahmouni, O., 1969, Ensemble de datage par Carbone 14 d'Alger: Rapport interne, Inst. d'études nucléaires d'Alger, service appl. nucléaires, AN/16/69. 
Brahimi, C., 1969, Ibero-Maurusien littoral de la région d'Alger: Liaison de l'assoc. Sénégalaise pour l'étude du quaternaire de l'Ouest Africain (ASEQUA) bull., Dakar. Faun. Sénégal, no. 22, June 1969 , p. 11.

Delibrias, G., Guillier, M. T., and Labeyrie, J., 1964, Saclay natural radiocarbon measurements I: Radiocarbon, v. 6, p. 233-250.

Grebenart, D., 1969, Aïn Naga: Capsien et néolithique-Messad, Dept. de Médéa: Lybica, v. 17, Paris, Arts et Métiers Graphiques, in press.

Houtermans, J., Suess, H. E., Munk, K. W., 1967, Effect of industrial fuel combustion on the carbon-14 level of atmospheric $\mathrm{CO}_{2}$ (SM-87/31) in: Radioactive dating and method of low level counting, I.A.E.A. and I.C.S.U. symposium, 2-10 March 1967, Monaco.

Libby, W. F., 1955, Radiocarbon dating, 2nd ed.: Chicago, Univ. of Chicago Press, ix, p. 175 .

Roubet, C., 1969, Interêt des datations obtenues pour le néolithique de tradition capsienne: Lybica, v. 17, Paris, Arts et Métiers Graphiques, in press.

Suess, H. E., 1965, Secular variation of the cosmic ray produced carbon-14 in the atmosphere and their interpretations: Jour. Geophys. Research, v. 70, no. 23, p. 5937-5952. 